
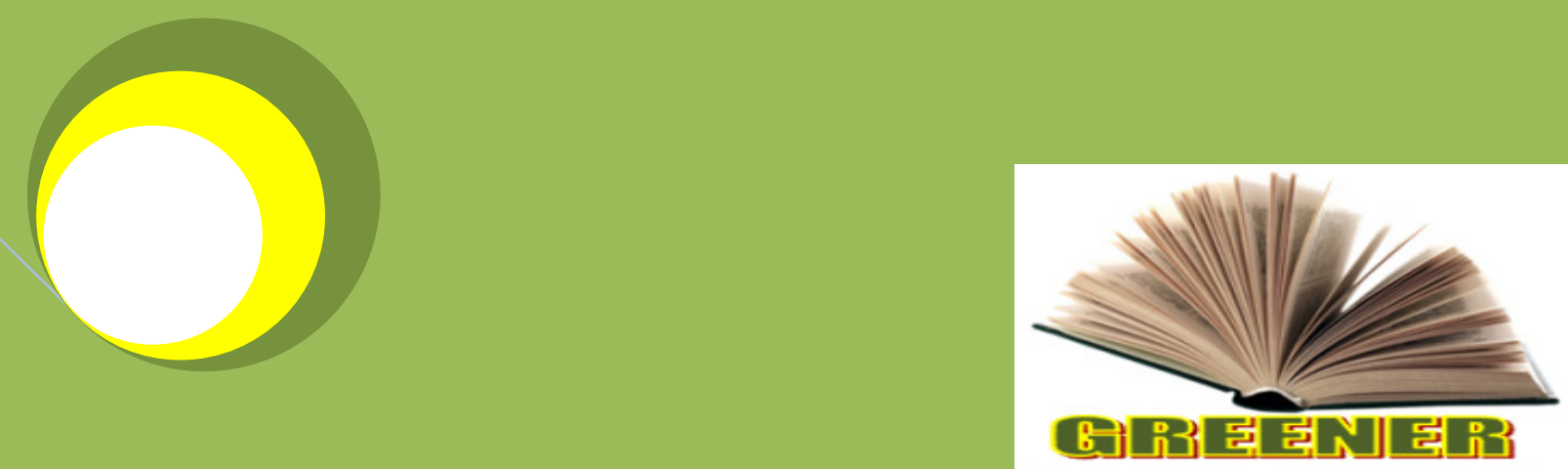

D(0) U U

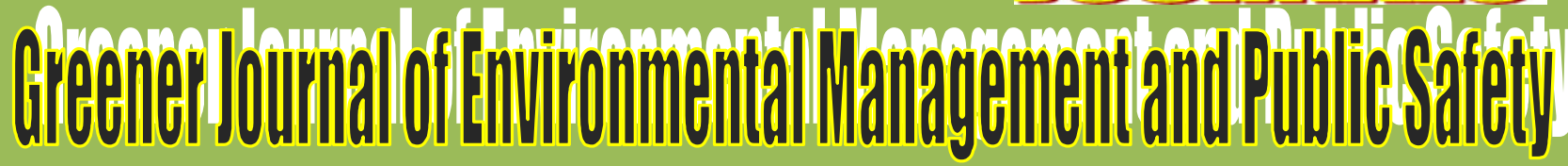

ISSN: 2354-2276

\title{
Implementation Study of ISO 14001- EMS Standards in Processing Unit of Nimra Textiles
}

By

Samia Sajid

Shafaqat Ali

Fozia Dogar

Muhammad Bilal Shakoor

Khadija Siddique

Lubna Taj 


\title{
Implementation Study of ISO 14001- EMS Standards in Processing Unit of Nimra Textiles
}

\author{
Samia Sajid, Shafaqat Ali, Fozia Dogar, \\ *Muhammad Bilal Shakoor, Khadija Siddique, Lubna Taj
}

\author{
Department of Environmental Sciences, Government College University, Allamalqbal Road, 38000, Faisalabad. \\ Pakistan. \\ *Corresponding Author's Email: bilalshakoor88@gmail.com
}

\begin{abstract}
Textile sector is often considered as the backbone of Pakistan's economy. It is the most important industrial sector in terms of export and involves human resource to a much greater extent. Apart from being one of the highest revenue generating sectors, it has several tribulations, one of them being the environmental pollution. Water, air and noise pollution and the solid waste generation are the main problems which turn out to be a serious health hazard for flora and fauna. Increasing global awareness about these environmental hazards has triggered international environment protection agencies and governments to impose stringent pollution regulations. International certification requirements for ISO 14001-EMS is also becoming essential dynamics of the global market. These standards are also implemented in Pakistan. If these standards are not followed precisely, the Pakistan textile products will start losing their competitive edge in the international markets. The purpose of this study is to develop better understanding of the textile processes, related environmental issues and the available techniques for controlling the environmental pollution and also to understand the components of ISO 14001 Environmental Management System (EMS). To achieve this goal, I worked with NEC Consultants (Pvt.) Ltd team in one of their projects: Cleaner Technology Program for Textile Industry (CTPT). The processes of ISO 14001-EMS implementation in Nimra Textile (Pvt.) Ltd (NTL) was studied in detail with help of literature review, industrial survey and checklists. By these tools, it was found that most of the environmental aspects of NTL were exceeding the NEQs and company was willing to improve its environmental performance. That's why the NTL takes services from NEC team as consultants. So, NEC team suggested them to implement ISO 14001-EMS standards in their company and provide guidance for its implementation.
\end{abstract}

Keywords: ISO 14001-EMS, toxic effluents, sustainable industrial development, textile industry, waste water.

\section{INTRODUCTION}

Textile industry is the largest and most viable industry in Pakistan. It generates water, air, noise pollution and solid waste. These types of pollution are generated from singing, de-sizing, bleaching, dyeing, printing and washing departments in processing textile industry. Pakistan is a developing country and trying to meet the International Standards for Environment and Management System.

Textile industry is the largest and most viable industry. Globalization has resulted in the expansion of a textile sector all over the world since 1995, consequently, environmental research on textile pollution problems has been increased worldwide (Moore and Ausley, 2004).

Large amount of water is used in dyeing and finishing processes of textile processing unit (Ozturk et al., 2009). A huge amount of wastewater is produced in industrial dyeing process, because when the dye changes, the production lines have to be washed out each time (Jiang et al., 2010). This process could release huge quantity of toxic effluents which would lead towards high restorative costs (Ren, 2000). Consequently, the amount of water released and the chemical load of textile effluents are the main environmental concern in this industry (Smith, 1996).

Air pollution is also generated in textile industry by fossil fuel fired combustors because of their flues and a variety of chemicals utilized in production processes (N.I.I.R. Board, 2004). Solid waste is also generated from textile processing units. Generally, the effluents discharged from textile industry are alkaline in nature and have high BOD, COD, conductivity and is highly colored. Microbial activity is inhibited in industrial waste water due to the presence of metals and dyes (Lo et al., 2011). 
The manufacturing of textile industry discharge large amount of pollutants to the environment. Corporate activities have an increased interest towards reducing or eradicating the waste produced in the production processes. Therefore, the adoption of environmental management systems (EMS) is important and could have a major impact on the operational performance of textiles industries (Melnyk et al., 2003).

As a result of increase in the general level of environmental understanding, there is an increasing interest in the environmental performance of industries. Some research has emerged due to the worldwide increase in the acceptance of environmental management systems (EMSs) that evaluates the reasons why facilities adopt them? (Srivastava, 2007). Many companies operate on international level and competition inspires them to look for economically preferable manufacturing alternatives (Nawrocka et al., 2009). This puts stress on companies to deal with environmental issues and produce products with an environmental profile that satisfies the consumer requirements, but also to inform about the environmental impacts of the production processes and of the products throughout their entire life cycle. To meet the rising market pressures and the terms of more demanding environmental legislation, many companies spend for environmental management and communication tools, such as, Standardized Environmental Management Systems (in particular ISO 14001), Life Cycle Assessments, Environmental Labeling of products etc (Lam et al., 2011).

Environmental Management System (EMS) has been one of the important tools for sustainable industrial development (UNE-EN 1996). EMS can be defined as "the part of the overall management system that includes organizational structure, planning activities, responsibilities, practices, procedures, processes and resources for developing, implementing, achieving, reviewing and maintaining the environmental policy" (EN, 2004).

Management standards that address environmental issues in organizations were continuously developed by The International Organization for Standardization (ISO). The standard which is commonly used is the environmental management system (EMS) standard ISO 14001(Coglianese andNash, 2001).

Environmental management systems in general consist of internal policies, evaluations, plans and implementation actions for industry (Arimura et al., 2008). ISO 14001 are globally known EMS standard. ISO 14001 need external third-party authentication to ensure that facilities conform to the ISO standard that differentiates these standards from noncertified systems (Benito and Benito, 2008). Within the management structure, an environmental management system (EMS) organization commit that they evaluate their environmental impact and to set goals for improvement and it is a continuous process. Its implementation permits the company to attain a certificate of compliance which proves that the EMS fulfills all the recognized requirements. The ISO 14001 certification has gained high levels of fame and the number of companies has increased very sharply which have ISO 14001 certification, since 1996 (Rivera-camino, 2001). The aims of corporation to meet the terms and legal requirements have been reported as significant motivating forces for implementing ISO 14001(Hillary, 2004) and its certificate can be a way to fulfill the customer's environmental requirements (Ibrahim, 2008).

The research was conducted in order to develop the methodology for ISO 14001-EMS implementation in the textile industry in such a way that textile industries will be enabled to control heavy pollution load using the best technologies available. These technologies were studied in detail to understand the environmental and economical benefits associated with their adaptation. Objectives of the research were to develop better understanding of the textile related environmental issues and to study the available materials/techniques for controlling the environmental pollution resulting from the textile industry.

Under PISDII, I have worked with NEC Consultants (Pvt) Ltd team in one of their project, Cleaner Technology Program for Textile industry (CTPT). Consultancy of EMS implementation is one of the components of CTPT. The process of EMS implementation in Nimra Textile (pvt.) Ltd was studied in detail.

\section{MATERIAL AND METHODS}

The research was conducted in 2011.

Selection of Industry for Case Study: Nimra Textile is one of the progressive industries situated in Khurrianwala. The industry was selected as a case study as it has taken several steps in improving the environmental impacts of its operations. All types of major textile processing are performed in the industry so it was possible to go through most of the environmental impacts related to textile processing.

Data Collection: In this step, detailed information about the industry was collected with the help of checklist. First of all, the data available in the textile industry was collected and reviewed. Later, the team conducted detailed field visits in the industry. 
Suggestions: Suggestions were made on the basis of findings of data assessment. The main focus of the suggestions was the implementation of the ISO 14001-EMS and pollution prevention technologies keeping in view the process and working environment improvements, resource optimization and at source pollution abatement possibilities.

Implementation of ISO 14001-EMS (Steps): To establish and maintain a procedure for implementing ISO 14001-EMS in textile industry, the following steps are taken:

1. Appointment of Environmental Management Representative (EMR).

2. Development of environmental policy.

3. Environmental scanning.

4. Identification of environmental aspects and their impacts.

5. Ranking of the aspects.

6. Selection of significant aspects.

7. Identification of legal and others requirements.

8. Preparation of objectives and targets and EMPs.

9. Development of EMS team within an organization.

10. Allocation of responsibilities to the EMS team member.

11. Preparation of documents.

12. Internal EMS audit.

13. External EMS audit.

14. Certification of ISO 14001.

15. Ongoing training session.

This study is focussed on Environmental scanning and Identification of environmental aspects and their impacts and suggesstions are given to industry for the implementation of ISO 14001 which covers all the steps.

\section{Purpose}

The purpose of this procedure is to provide a system and procedure to identify environmental aspects of activities, products, and services and list down those, which may have significant impact on the environment.

\section{Forms}

- $\quad$ Process Evaluation Checklist (Annexure I)

- $\quad$ Form for Environmental Aspects and Impacts Worksheet (Annexure II)

- $\quad$ Form for Significant Environmental Aspects Worksheet (Annexure III)

\section{Procedure}

1. EMR and EMS Team shall initially identify the environmental aspects by completing attached form Annexure-I to this section, for each process and supporting activity within the facility of the Industry. Members of the EMS Team must conduct a physical inspection and shall complete the form given in Annexure I of this procedure.

2. Environmental Aspects identified by the team shall be discussed with the departmental heads in an. EMS team shall evaluate the significance of an environmental aspect by using the Significant Environmental Aspect Worksheet attached as (Annexure III).

3. Significance of aspects associated with each process shall be determined by using worksheet presented as Annexure III (Significant Environmental Aspect Worksheet) of this procedure.

4. Impact significance in work sheet shall be calculated through following formula;

$$
\begin{aligned}
S R & =R+(E+F) \\
R & =(A+B) \times(C+D) \\
S R & =(A+B) \times(C+D)+(E+F)
\end{aligned}
$$

Where;

$$
\begin{aligned}
& S R=\text { Significance Rating } \\
& R=\text { Risk Rating }
\end{aligned}
$$




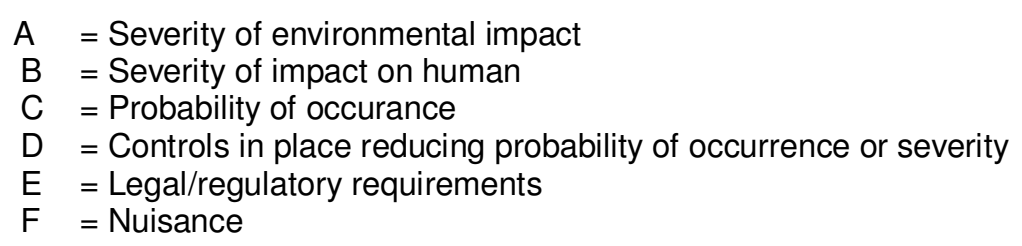

\section{RESULTS AND DISCUSSION}

\section{Basic Site Information}

1. Industrial Unit: Nimra Textile (Pvt.) Ltd "fig 1"

2. Location: 5 K.M Jhumra Road Khurrianwala, Faisalabad.

3. Certification: ISO 9001

4. No. of Employees: 400

5. Organization In charge: Chief Executive Officer (CEO)

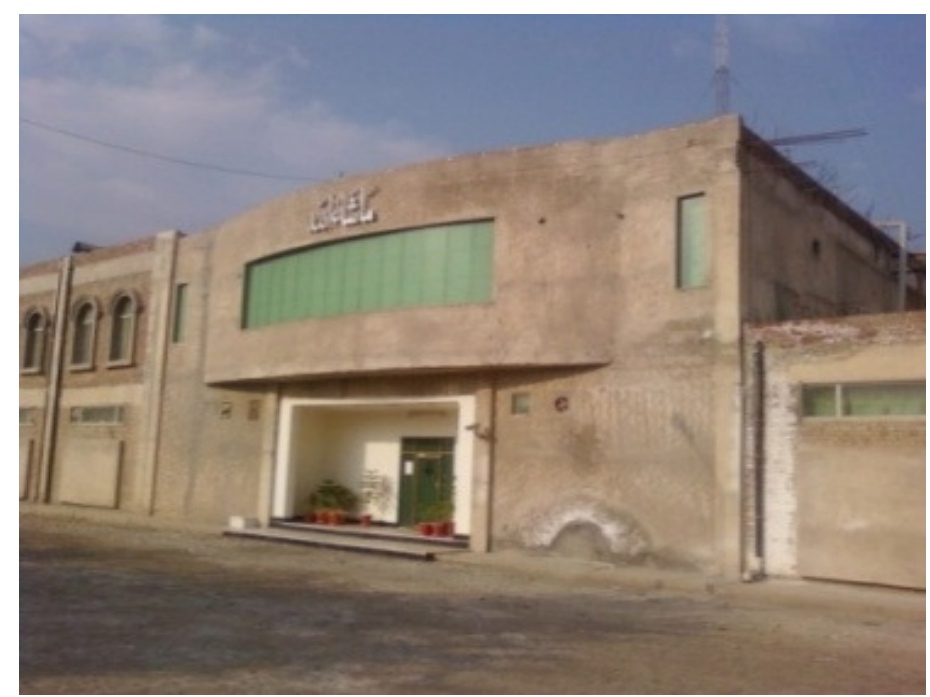

Figure no 1:Nimra Textile (Pvt.) Ltd

\section{Effluent Discharge}

Waste water from pretreatment, dying, printing and finishing sections was collected separately through small pipes into a main drain surrounding a processing hall. At the end of which small size settling tanks was there where the effluents were retained for some duration for sedimentation. Finally the effluents were discharged into SaimNullah.

\section{Environmental aspects and impacts of NTL}

\section{Wastewater}

In textile processing industry, large amount of water was used during dyeing and finishing processes. The chemical loads in water were generated mainly due to the residues from pretreatment, dyeing, finishing, sizing and other operations. Therefore, the amount of water discharged and the chemical load of textile effluents were the major environmental concern in the textile industry (Ozturk et al., 2008).

Water hoses were used to wash chemical drums, process vessels, machines and floors, due to carelessness of workers a large amount of water was wasted here, which results in high electricity cost . 
NTL's primary treatment consists of two small settling tanks. Due to small primary treatment is ineffective. The average estimated effluent wastewater flow is $2,062 \mathrm{~m}^{3} /$ day. So the effluents discharged are not in compliance with National Environment Quality Standard (NEQS).

\section{Wastewater Flow Monitoring}

Flow metering was carried out in the supervision of PISD Team and was continued for continuous $24 \mathrm{hrs}$. After half an hour, proportionate sample was collected and stored in ice box. During the flow monitoring, composite sample was prepared through collected 48 samples. The composite sample was sent to EPA approved lab for analysis regarding wastewater parameters.

Table 1: Wastewater Analysis

\begin{tabular}{|l|l|l|l|}
\hline No & Parameters & Test Results & NEQS \\
\hline 1 & pH & 8.1 & $6-9$ \\
\hline 2 & Chemical Oxygen Demand (COD) $\mathrm{mg} / \mathrm{l}$ & 1,361 & 150 \\
\hline 3 & Biochemical Oxygen Demand (BOD mg/l $^{\mathrm{m}}$ & 548 & 80 \\
\hline 4 & Total Suspended Solids (TSS) $\mathrm{mg} / \mathrm{l}$ & 292 & 200 \\
\hline 5 & Total Dissolved Solids (TDS) $\mathrm{mg} / \mathrm{l}$ & 3,153 & 3,500 \\
\hline 6 & Chromium $(\mathrm{Cr}) \mathrm{mg} / \mathrm{l}$ & 0.026 & 1.0 \\
\hline 7 & Copper $(\mathrm{Cu}) \mathrm{mg} / \mathrm{l}$ & 0.093 & - \\
\hline 8 & Oil \& Grease & 43 & - \\
\hline
\end{tabular}

Table 1.1: Comparison of Combined Wastewater Treatment Systems

\begin{tabular}{|l|c|c|c|c|c|}
\hline \multicolumn{1}{|c|}{ Process } & $\begin{array}{c}\text { BOD } \\
\text { Removal } \\
(\%)\end{array}$ & $\begin{array}{c}\text { COD } \\
\text { Removal } \\
(\%)\end{array}$ & $\begin{array}{c}\text { Color } \\
\text { Removal } \\
(\%)\end{array}$ & $\begin{array}{c}\text { Unit Capital } \\
\text { Cost }\end{array}$ & $\begin{array}{c}\text { Unit O\&M } \\
\text { Cost }\end{array}$ \\
\hline $\begin{array}{l}\text { Activated Sludge Process } \\
\text { (Extended Aeration) }\end{array}$ & $70-90$ & $50-70$ & $0-20$ & $\begin{array}{c}9,000- \\
12,000\end{array}$ & $5.0-6.5$ \\
\hline Anaerobic Pretreatment & & $30-40$ & $30-40$ & & $0.5-1.0$ \\
\hline Chemical Coagulation & $40-70$ & $40-70$ & $0-70$ & $5,000-$ & $25-50$ \\
\hline $\begin{array}{l}\text { Anaerobic Pretreatment + } \\
\text { Activated Sludge Process } \\
\text { (Extended Aeration) }\end{array}$ & $80-95$ & $65-80$ & $50-70$ & 11,000 & \\
\hline $\begin{array}{l}\text { Chemical Coagulation + } \\
\text { Activated Sludge Process } \\
\text { (Extended Aeration) }\end{array}$ & $80-95$ & $65-80$ & $0-80$ & 15,000 & $2.5-4.0$ \\
\hline
\end{tabular}

Table 1.2 : Process Wise Chemical Consumption

\begin{tabular}{|l|c|c|}
\hline \multicolumn{1}{|c|}{ Process } & Chemicals & $\begin{array}{c}\text { Unit Consumption } \\
\text { (g/kg of fabric) }\end{array}$ \\
\hline Desizing & Desizer & 2.27 \\
\hline \multirow{2}{*}{ Scouring and } & Caustic Soda (NaOH)-50\% & 48.91 \\
\cline { 2 - 3 } Bleaching & Hydrogen peroxide $(\mathrm{H} 2 \mathrm{O} 2)$ & 13.49 \\
\cline { 2 - 3 } & Sodium Silicate & 6.57 \\
\hline & Soda Ash & 5.56 \\
\hline Neutralization & Hydrochloric acid $(\mathrm{HCl})$ & 25.3 \\
\hline Printing & Urea & 0.186 \\
\cline { 2 - 3 } & Amonia Liquor & 3.60 \\
\hline
\end{tabular}


The results in table 1 indicated that most of the parameters were above NEQS permissible values. The value of COD, BOD and TSS are above and the value of $\mathrm{pH}$, TDS and heavy metals are in compliance with NEQS permissible limits.

Lo et al., 2011 showed that the production of textiles related products often requires high levels of energy and water consumption, and emits large quantities of pollutants to the environment. Therefore, the adoption of environmental management systems (EMSs) is important and could have a significant impact on these firms' operational performance. This study is in compliance with the results.

Xie et al., 2011 estimated that Industrial dyeing processes generate a huge amount of wastewater, because the production lines have to be washed out each time when the dye changes. This study also shows that dying process of textile industry produce large amount of waste water and correlates with the results.

\section{Water Conservation Measures}

Following water conservation measures are recommended for the industry:

\section{Reuse of RO Rejected Water}

When RO plant is operated at lower capacities large volumes of rejected water is generated.. This water can be used in bulk washing after mixing with ground water.

\section{Reuse of Singeing Cooling Water}

Singeing cooling water $\left(43.2 \mathrm{~m}^{3} /\right.$ day) is wasted regularly. It is a clean water stream, which can be collected and directly used on all places where turbine water is used.

\section{Monitoring of Water}

It is important to monitor and record water quantity in the production processes before implementation of any of the recovery, recycle and reuse options.

\section{Water Shut Off Valves on Water Hoses}

All the water hoses used in the production area to clean paste drums, printing screens, machines and floors should be fitted with water shut off valves of appropriate size and type.

\section{Suggested Wastewater Treatment Technologies}

Technically appropriate and practicable treatment systems, suited to local conditions, comprise of combination of available treatment technologies. These treatment technologies are presented in the Table 1.1, for the treatment of the combined processing wastewater. The table also summarizes the ranges of achievable treatment efficiencies, unit capital costs and unit operation and maintenance (O\&M) costs, for these treatment systems.

Table 1.1 reveals that activated sludge process, following an anaerobic treatment process (like UASB), appears to be the best possible system, for the treatment of combined wastewater. In cases, where the above proposed treatment system, is unable to meet the NEQS completely, especially for COD removal, or where enhanced color removal is required, chemical coagulation process, in case of colloidal dyestuff like dispersed, vat and sulfur dyes, and chemical oxidation in case of dissolved dyestuff, like reactive and direct dyes, shall be added to the anaerobic-aerobic treatment system.

\section{Process Chemicals}

It was observed that workers add chemicals in the process vessels and chemical preparation tanks of estimated quantities, with accurate measurement by using digital balance.

It is difficult to exactly analyze all the chemicals because many chemicals are supplied with manufacturer brand names and are combinations of different chemicals compounds. However, information about some of the major chemicals used in the pretreatment processes were analyzed to calculate the amount of chemicals consumed to process one $\mathrm{kg}$ of finished fabric, as presented in Table 1.2. 
The information of the chemicals provided by the industry was also checked to confirm that if there are any internationally banned chemicals. All these chemicals are commonly used and acceptable in the international market. However, this chemical consumption was compared with some typical ranges of the recipes given in the

International literature (IPPC-Reference Document on Best Available Techniques for the Textile Industry-2003 by European Commission). The consumption of the given chemicals in NTL is generally within respective ranges as prescribed in International literature.

\section{Air Emission:}

Pollutants were emitted from stacks of textile unit. These pollutants had adverse environmental impacts on ambient air quality. Stack analysis is performed after every six months in the industry and its record is maintained.

\section{Air Emission Monitoring}

According to EPA, the parameters for the air emissions of textile industry are CO, SOx, NOx and Particulate matters. As the industry has no stack analyzer, so the management of NTL uses external sources to conduct the stack analysis of boiler and oil heaters. According to schedule recent stack analysis that was performed in Oct 2010. The results of the analysis are given in the table 2 and 3.

Table 2: Boiler Stack Analysis Results

\begin{tabular}{|l|l|l|l|}
\hline Parameter & Unit & Results & NEQS \\
\hline Temperature of flue gas & ${ }^{\circ} \mathrm{C}$ & 209 & ---- \\
\hline Temperature $(\mathrm{ambient})$ & ${ }^{\circ} \mathrm{C}$ & 37 & \\
\hline Sulfur dioxide $\left(\mathrm{SO}_{2}\right)$ & $\mathrm{mg} / \mathrm{Nm}^{3}$ & 1.0 & ---- \\
\hline Nitrogen Oxides(NOx) $\left(\mathrm{NO}_{2}+\mathrm{NO}\right)$ & $\mathrm{mg} / \mathrm{Nm}^{3}$ & 77 & 400 \\
\hline Nitric Oxide $(\mathrm{NO})$ & $\mathrm{mg} / \mathrm{Nm}^{3}$ & $\mathrm{NA}$ & ---- \\
\hline Nitrogen dioxide $\left(\mathrm{NO}_{2}\right)$ & $\mathrm{mg} / \mathrm{Nm}^{3}$ & $\mathrm{NA}$ & ---- \\
\hline Carbon monoxide $(\mathrm{CO})$ & $\mathrm{mg} / \mathrm{Nm}^{3}$ & 0.0 & 800 \\
\hline Hydrocarbons $(\mathrm{HCs})$ & $\%$ & $\mathrm{NA}$ & \\
\hline Carbon dioxide $\left(\mathrm{CO}_{2}\right)$ & $\%$ & 10.3 & ---- \\
\hline Oxygen $\left(\mathrm{O}_{2}\right)$ & $\%$ & 2.6 & - \\
\hline Efficiency & $\%$ & 92.2 & \\
\hline
\end{tabular}

Table 3: Oil Heater \# 01 Stack Analysis Results

\begin{tabular}{|l|l|l|l|}
\hline Parameter & Unit & Results & NEQS \\
\hline Temperature of flue gas & ${ }^{\circ} \mathrm{C}$ & 324 & ---- \\
\hline Temperature $($ ambient) & ${ }^{\circ} \mathrm{C}$ & 33 & \\
\hline Sulfur dioxide $\left(\mathrm{SO}_{2}\right)$ & $\mathrm{mg} / \mathrm{Nm}^{3}$ & 0 & ---- \\
\hline Nitrogen Oxides(NOx) $\left(\mathrm{NO}_{2}+\mathrm{NO}\right)$ & $\mathrm{mg} / \mathrm{Nm}^{3}$ & 32 & 400 \\
\hline Nitric Oxide $(\mathrm{NO})$ & $\mathrm{mg} / \mathrm{Nm}^{3}$ & $\mathrm{NA}$ & ---- \\
\hline Nitrogen dioxide $\left(\mathrm{NO}_{2}\right)$ & $\mathrm{mg} / \mathrm{Nm}^{3}$ & $\mathrm{NA}$ & ---- \\
\hline Carbon monoxide $(\mathrm{CO})$ & $\mathrm{mg} / \mathrm{Nm}^{3}$ & 6.0 & 800 \\
\hline Hydrocarbons $(\mathrm{HCs})$ & $\%$ & $\mathrm{NA}$ & \\
\hline Carbon dioxide $\left(\mathrm{CO}_{2}\right)$ & $\%$ & 7.4 & ---- \\
\hline Oxygen $\left(\mathrm{O}_{2}\right)$ & $\%$ & 7.8 &. \\
\hline Efficiency & $\%$ & 83.1 & \\
\hline
\end{tabular}

Impacts of air emissions from the processing industry compared to the impacts of wastewater discharges were considered relatively less important because of natural gas combustion which is clean fuel when compared with liquid (Furnace oil, diesel) or solid fuels (coal, wood, husk, straw). The air pollution monitoring data showed that air emissions of gas fired boilers are generally in compliance with the NEQS. 
Ibrahimet al., 2008 showed that textile industry is the second largest industry and as small and mediumsized enterprises (SMEs) make up a great proportion of the total industry, it is desirable to attempt to decrease the pollution resulting from them for both economical and environmental advantages. In this regard, a case was investigated which dealt with pollution prevention of textile products. This study also supports our results.

\section{Noise Pollution}

Noise pollution existed in the textile processing unit due to the heavy machinery, equipped with moving and rotating parts, which result into elevated noise levels at the work place. Processing areas were generally packed with all sorts of equipment and machinery, without any confinement or noise barriers, resulting into noise dispersion from one location to other. Rangers of measured noise levels, based on a available past data, NEQs permissible noise level limit is $85 \mathrm{db}(\mathrm{A})$, at a distance of 7.5 meters from the source (Tripatty 1999).

\section{Noise Monitoring}

Significant noise producing areas were identified in NTL. Noise levels were measured in these areas of the production hall using a TES 1351 sound meter.

American Conference of Government Industrial Hygienists (ACGIH) has recommended a safe noise exposure limit of $85 \mathrm{~dB}(\mathrm{~A})$, where the worker can work for 8 hours in a day. Comparing the noise monitoring data of NTL shown in table 4, it is evident that some of the areas are exceeding this safe noise exposure limit. The noise monitoring results indicated that the noise levels are significant in service units i.e. generator room, boiler house, compressor room, RO plant, in processing hall jiggers section and drying range areas are noisy areas. Noise data indicates that the sound proofing in power house control room and boiler engineer's office is satisfactory.

Table 4: Noise Levels

\begin{tabular}{|l|l|l|l|}
\hline Sr.\# & Source & Noise Level dB(A) & $\begin{array}{l}\text { Permissible limit } \\
\text { dB(A) }\end{array}$ \\
\hline \multicolumn{2}{|l|}{ Processing Hall Machine Areas } & \\
\hline $\mathbf{1}$ & Grey Fabric Storage & 84 & 85 \\
\hline $\mathbf{2}$ & Singeing Desizing & 94 & 85 \\
\hline $\mathbf{3}$ & Kier Section & 89 & 85 \\
\hline $\mathbf{4}$ & Drying Ranges & 93 & 85 \\
\hline $\mathbf{5}$ & Jiggers Section & 91 & 85 \\
\hline $\mathbf{6}$ & Rotary Printing & 88 & 85 \\
\hline $\mathbf{7}$ & Rotary Printing Color Kitchen & 88 & 85 \\
\hline $\mathbf{8}$ & Flatbed Panel Printing & 87 & 85 \\
\hline 9 & Stenter 1 (IR) & 86 & 85 \\
\hline 10 & Stenter 2 & 86 & 85 \\
\hline 11 & Stenter 3 & 88 & 85 \\
\hline 12 & Calendars & 87 & 85 \\
\hline Service Units & 95 & \\
\hline 13 & Boiler House & 87 & 85 \\
\hline 14 & Boiler Engineer Office & 94 & 85 \\
\hline 15 & RO Plant & 94 & 85 \\
\hline 16 & Compressor Room & 98 & 85 \\
\hline 17 & Generator Room & 85 \\
\hline 18 & Power House Control Room & 78 & 85 \\
\hline 19 & Power House LT Panel Room & 82 & 85 \\
\hline 20 & Oil heater Room & 94 & 85 \\
\hline Workshops and Store & & \\
\hline 21 & Mechanical Workshop & 87 & 85 \\
\hline 22 & Electrical Workshop & 78 & 85 \\
\hline 23 & Main Store & 80 & 85 \\
\hline
\end{tabular}




\section{Lighting Conditions}

There is one processing hall in the industry having the satisfactory lightening system. It was observed that structure of processing hall roof is very efficient in providing sun light properly. The digital light meter, model No. TES 1330A was used to monitor light intensity during the day time.

The overall light condition of the processing unit is fairly satisfactory. It was observed during visit that design structure of processing hall roof is very efficient in providing sun light properly. Table 5 presents the list of the areas where light monitoring was conducted. Illumination data demonstrates that lighting conditions in the unit need improvement.

Table 5: Lighting Data

\begin{tabular}{|l|l|l|l|}
\hline Sr.\# & Source & Light Level (Lux) & Permissible limit (Lux) \\
\hline Processing Hall Machine Areas & \\
\hline $\mathbf{1}$ & Grey Fabric Storage & 220 & 250 \\
\hline $\mathbf{2}$ & Singeing Desizing & 450 & 250 \\
\hline $\mathbf{3}$ & Batching Area & 420 & 250 \\
\hline $\mathbf{4}$ & Kier Section & 275 & 250 \\
\hline $\mathbf{5}$ & Drying Ranges & 300 & 250 \\
\hline $\mathbf{6}$ & Jiggers Section & 150 & 250 \\
\hline $\mathbf{7}$ & Rotary Printing & 580 & 250 \\
\hline $\mathbf{8}$ & Rotary Printing Color Kitchen & 300 & 250 \\
\hline $\mathbf{9}$ & Flatbed Panel Printing & 700 & 250 \\
\hline 10 & Stenter 1 (IR) & 195 & 250 \\
\hline 11 & Stenter 2 & 220 & 250 \\
\hline 12 & Stenter 3 & 200 & 250 \\
\hline 13 & Calendars & 200 & 250 \\
\hline Service Units & \multicolumn{2}{|l|}{} \\
\hline 14 & Boiler House & 200 & 250 \\
\hline 15 & Boiler Engineer Office & 190 & 250 \\
\hline 16 & RO Plant & 220 & 250 \\
\hline 17 & Compressor Room & 70 & 250 \\
\hline 18 & Generator Room & 250 & 250 \\
\hline 19 & Power House Control Room & 80 & 250 \\
\hline 20 & Power House LT Panel Room & 100 & 250 \\
\hline 21 & Oil heater Room & 150 & 250 \\
\hline Workshops and Store & \multicolumn{2}{|l|}{} \\
\hline 22 & Mechanical Workshop & 130 & 250 \\
\hline 23 & Electrical Workshop & 400 & 250 \\
\hline 24 & Main Store & 120 & 250 \\
\hline S & PISD & \\
\hline
\end{tabular}

Source: PISD

\section{Solid Waste}

Table 6: Solid Waste Sources and Types

\begin{tabular}{|l|l|l|}
\hline Sr.\# & Source & Type of Solid Waste \\
\hline 1 & Processing & Waste fabric (rejection) \\
\hline 2 & Chemical Store & $\begin{array}{l}\text { Empty chemical drums of plastic and metal, empty } \\
\text { cardboards, polythene bags }\end{array}$ \\
\hline 3 & General & $\begin{array}{l}\text { Discarded machine and mechanical parts, metal scrap, } \\
\text { lube oil drums, IT Accessories, timber, paper etc }\end{array}$ \\
\hline
\end{tabular}

NTL processing unit produced variety of solid waste containing metal containers, plastic bags, plastic drums, polythene bags etc., which was mostly non-hazardous shown in table 6. Major portion of the solid waste is sold in scrap market. The solid waste yard was maintained in a good way with a proper segregation of the waste. In 
NTL, proper placement of the scrap and solid waste was not so well. Empty vessels were thrown as is it in vacant area near oil heater room and water turbine. Scrap material is dumped near compressed air receiver tank. Cotton rags were found near settling tanks made for effluent.

The entire waste fabric cutting produced at the mill was sold for normal. Others like papers, plastics, empty containers, cardboards, boxes and bags were either reused in the industry or sold to the scrap brokers for reuse or recycling purpose.

\section{Solid Waste Management}

It is recommended that the management should establish solid waste management system in the organization to keep record of all the solid waste produced in the mill, its proper storage and disposal. It is suggested that proper place for waste yard is assigned and maintained.

- Each departmental head or incharge will be responsible to segregate different types of wastes, generated in his department, in appropriate containers and keep record of their production. This record will include the type of waste, its quantity and generation rate.

- Store incharge will keep record of section wise solid waste received and keep them at allocated places

- Store incharge will dispose each category of the waste in accordance with the environmentally safe procedures, as established by the company

- The waste yard should be covered to protect it from the rain water. Rain water, contaminated with the oil and chemicals can percolate into the soil and contaminate the groundwater

- Empty chemical containers should not be placed on the unpaved floors, the spills and leaks of these chemicals from the containers can also pollute the soil and groundwater resource

- Different qualities of bleached rejected fabric waste should not be mixed together

\section{CONCLUSION}

Most of the environmental aspects of NTL were exceeding the NEQs and the company wanted to improve their environmental performance. That's why industry took services from PISD team as consultants. So, PISD team suggested them to implement ISO 14001-EMS standards in their company and provide guidance for its implementation.

\section{ACKNOWLEDGEMENT}

I like to express my profound gratitude to respected supervisor MRS. FOZIA DOGAR for her cooperation during my research work. I am extremely thankful to the Project coordinator MR. MUHAMMAD YASEEN KHAN, EMS Expert MRS. SABRA KANWAL (co-supervisor) and all members of PISD team whose guidance, attention and knowledge guided me toward the successful completion of this project. I am also thankful to the management and employees of the textile industry especially General Manager ABDUL AZIZ, Quality Manager MR. QAMAR and Mechanical Engineer MR. SHAKEEL who helped me in the experiments, surveys, interviews and questionnaires.

\section{REFERENCES}

Moore, S. B. and Ausley, L. W., (2004). Systems thinking and green chemistry in the textile industry: concepts, technologies and benefits, Journal of Cleaner Production. 12: 585-601.

Ozturk, E. Yetis, U.,Dilek, F. Band Demirer, G.N., (2009). A chemical substitution study for a wet processing textile mill in Turkey, Journal of Cleaner Production, 17:239-247.

Jiang, W. Yuan, Z. Bi J and Sun, L., (2010). Conserving water by optimizing production schedules in the dyeing industry, Journal of Cleaner Production. 18: 1696-1702.

Ren, X., (2000). Development of environmental performance indicators for textile process and product, Journal of Cleaner Production8: 473-481.

Smith, B., (1994). Future pollution prevention opportunities and needs in the textile industry. In: B. Pojasek, Editor, Pollution prevention needs and opportunities, Center for Hazardous Materials Research.

N.I.I.R. Board, (2004). Textile Processing with Effluents Treatment, Asia pacific business, India, 600-601. 
Lo, C.Y.K.Yeung, A.C.Land Cheng, T.C.E., (2011). The impact of environmental management systems on financial performance in fashion and textiles industries. International Journal of Production Economics.

Melnyk, S. A., Sroufe, R. P. and Calantone, R., (2003). Assessing the impact of environmental management systems on corporate and environmental performance.Journal of Operations Management. 21: $329-353$.

Srivastava, S. K., (2007). Green supply-chain management: a state-of-the-art literature review. International Journal of Management Reviews.9: 53-80.

Lam, P. T. I., Chan, E. H. W., Chau, C. K., Poon, C. and Sand Chun, K.P., (2011). Environmental management system vs green specifications: How do they complement each other in the construction industry? Journal of Environmental Management, 92: 788-795. UNE-EN ISO 14001,Sistemas de GestiónMedioambiental.Especificaciones y directricesparasuutilización (ISO 14001:1996).AENOR. Madrid EN ISO 14001, (2004). Environmental management systems - requirements with guidance for use, International Organisation for Stardardisation.

Coglianese, C and Nash, J., (2001). Editors, Regulating from the Inside: Can Environmental Management Systems Achieve Policy Goals? Resources for the Future, Washington.

Arimura, T. H., Hibiki, A and Katayama, H., (2008). Is a voluntary approach an effective environmental policy instrument? A case for environmental management systems, Journal Environmental Economics Management,55: 281-295.

Benito, J. G and Benito, O. G., (2008). Operations management practices linked to the adoption of ISO 14001: An empirical analysis of Spanish manufacturers. International Journal of Production Economics, 113:60-73.

Rivera-camino, J., (2001). What motivates European firms to adopt environmental management systems? EcoManagement and Auditing,8:134-143.

Hillary, R., (2004). Environmental management systems and the smaller enterprise. Journal of Cleaner Productio, 12: 561-569.

Ibrahim, N. A., Moneim, N. M. A Halim. E. S. A and Hosni, M. M., (2008). Pollution prevention of cotton-cone reactive dyeing.Journal of Cleaner Production, 16:1321-1326.

Tripatty, D.P., (1999). Noise Pollution, APH Publishing Corporation, India, 3.

Xie, K., Cheng, F., Zhao, W., Xu, L., (2011). Micelle dyeing with low liquor ratio for reactive dyes using dialkyl maleic acid ester surfactants, journal of Cleaner Production, 19(4), 2011, 332-336.

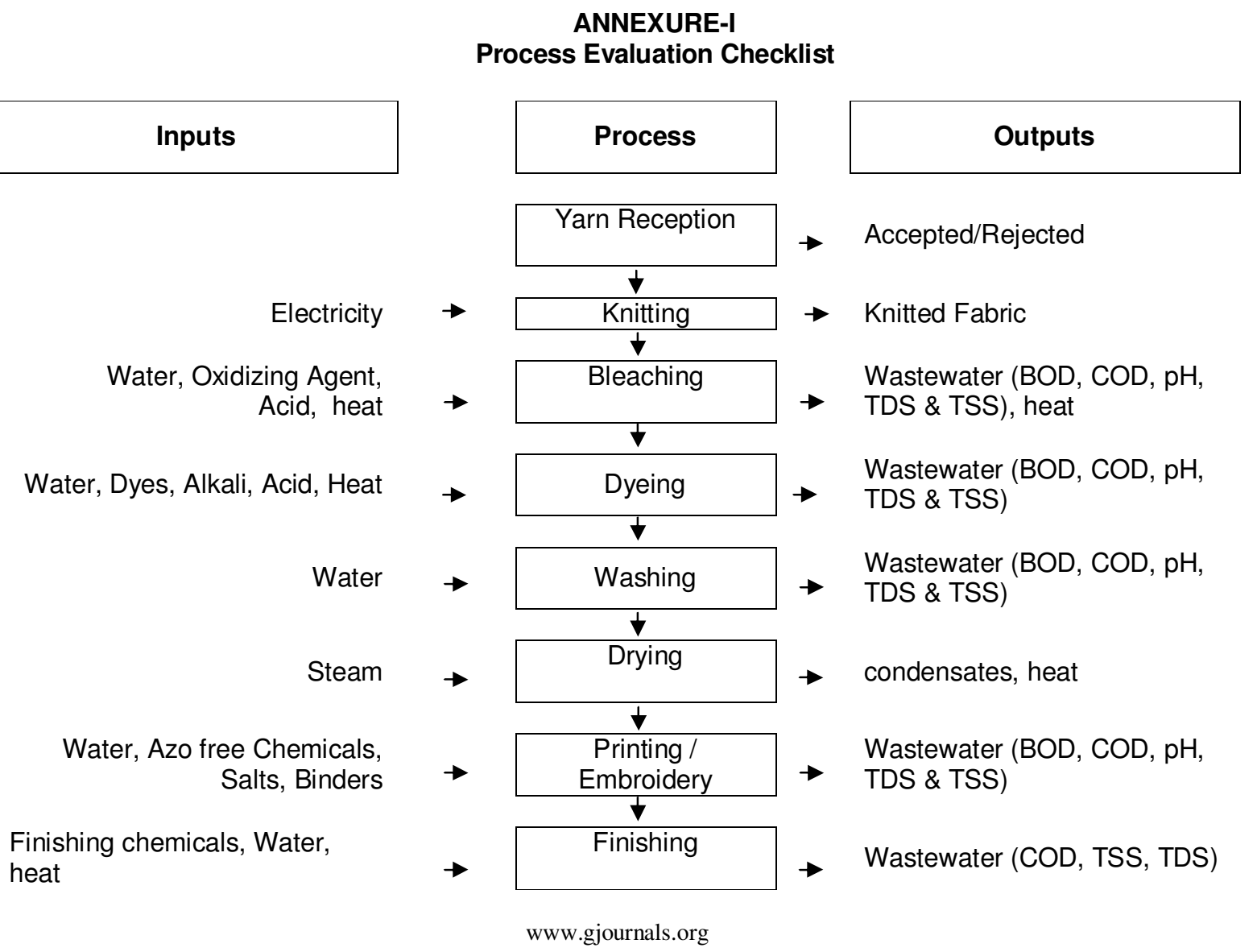


ANNEXURE-II

Environmental Aspects and Impacts Worksheet

\begin{tabular}{|c|c|c|c|c|}
\hline Sr. & Environmental Aspects & $\begin{array}{l}\text { Sources /Activities/ } \\
\text { Services }\end{array}$ & $\begin{array}{l}\text { Potential Environmental } \\
\text { Impacts }\end{array}$ & Current Measures \\
\hline \multicolumn{5}{|c|}{ Environmental Issues } \\
\hline & Waste water & $\begin{array}{l}\text { Bleaching, Dyeing, } \\
\text { Washing }\end{array}$ & $\begin{array}{l}\text { Water pollution and human } \\
\text { health hazards }\end{array}$ & No measures \\
\hline & Water wastages & $\begin{array}{l}\text { Bleaching, Dyeing, } \\
\text { Washing }\end{array}$ & Water resource depletion & No measures \\
\hline & Wastages of cooling water & $\begin{array}{l}\text { Compressors, } \\
\text { generators, cooling } \\
\text { tower }\end{array}$ & $\begin{array}{l}\text { Water resource depletion, } \\
\text { Increase in hydraulic load for } \\
\text { treatment facility }\end{array}$ & No measures \\
\hline & \multirow{7}{*}{ Air Emissions } & Oil heater (flue gas) & \multirow{7}{*}{ Air Pollution } & \multirow{5}{*}{ No measures } \\
\hline & & Stenter & & \\
\hline & & Tumble dryers & & \\
\hline & & Rope machines & & \\
\hline & & Finishing & & \\
\hline & & Generator & & $\begin{array}{l}\text { Generators are kept out } \\
\text { side the facility which is } \\
\text { serious risk towards } \\
\text { Health, Safety \& } \\
\text { Environment }\end{array}$ \\
\hline & & Boiler & & $\begin{array}{l}\text { Preventive } \\
\text { maintenance of boiler }\end{array}$ \\
\hline & VOCs & Stenter & Air Pollution & No Measures \\
\hline & \multirow{5}{*}{ Solid waste } & Processing & \multirow{5}{*}{ Air and soil pollution } & \multirow{5}{*}{ No measures } \\
\hline & & Packing & & \\
\hline & & Chemical store & & \\
\hline & & Office work & & \\
\hline & & Maintenance & & \\
\hline & Chemical handling & $\begin{array}{l}\text { Processing hall and } \\
\text { chemical store }\end{array}$ & $\begin{array}{l}\text { Health hazards \& workers } \\
\text { safety }\end{array}$ & $\begin{array}{l}\text { Chemicals are not } \\
\text { stored on the basis of } \\
\text { their physical } \\
\text { properties }\end{array}$ \\
\hline & Chemical storage & $\begin{array}{l}\text { Processing hall and } \\
\text { Chemical store }\end{array}$ & Soil \& air pollution & No measures \\
\hline & $\begin{array}{l}\text { Un covered Moving parts } \\
\text { of machines }\end{array}$ & $\begin{array}{l}\text { drum dryers and oil } \\
\text { heaters, belt driven } \\
\text { broomwade } \\
\text { compressor }\end{array}$ & Risks to health \& safety & No measures \\
\hline
\end{tabular}




\begin{tabular}{|c|c|c|c|c|}
\hline $\begin{array}{l}\text { Sr. } \\
\#\end{array}$ & Environmental Aspects & $\begin{array}{l}\text { Sources /Activities/ } \\
\text { Services }\end{array}$ & $\begin{array}{l}\text { Potential Environmental } \\
\text { Impacts }\end{array}$ & Current Measures \\
\hline \multicolumn{5}{|c|}{ Energy Issues } \\
\hline & lack of insulation & $\begin{array}{l}\text { Steam distribution } \\
\text { system }\end{array}$ & Loss of thermal energy & $\begin{array}{l}\text { Insulation at some pipe } \\
\text { lines }\end{array}$ \\
\hline & Steam leakages & $\begin{array}{l}\text { Steam Pipelines and } \\
\text { fittings }\end{array}$ & Loss of thermal energy & $\begin{array}{l}\text { Some work on } \\
\text { leakages }\end{array}$ \\
\hline & $\begin{array}{l}\text { Wastage of warm water } \\
\text { streams }\end{array}$ & $\begin{array}{l}\text { Cooling water, } \\
\text { generator, } \\
\text { Compressors }\end{array}$ & Loss of thermal energy & No measures \\
\hline & $\begin{array}{l}\text { Discharge of hot flue } \\
\text { gases }\end{array}$ & $\begin{array}{l}\text { Stenter, Boiler, } \\
\text { Therm oil heater }\end{array}$ & Loss of thermal energy & $\begin{array}{l}\text { No heat is recovered at } \\
\text { any source }\end{array}$ \\
\hline & Uncontrolled heating & Rope & Loss of thermal energy & No measures \\
\hline & $\begin{array}{l}\text { Poorly maintained } \\
\text { Electrical Distribution } \\
\text { System }\end{array}$ & Process Hall & $\begin{array}{l}\text { Health \& Safety risks, } \\
\text { Loss of energy }\end{array}$ & No measures \\
\hline & $\begin{array}{l}\text { High pressure set points } \\
\text { (At } 8.5 \text { bar) }\end{array}$ & Compressor & Loss of energy & No measures \\
\hline & $\begin{array}{l}\text { Compressed Air } \\
\text { Leakages }\end{array}$ & $\begin{array}{l}\text { Compressed Air } \\
\text { applications }\end{array}$ & Loss of energy & $\begin{array}{l}\text { Some work on } \\
\text { leakages }\end{array}$ \\
\hline & $\begin{array}{l}\text { Cleaning with } \\
\text { Compressed Air }\end{array}$ & Maintenance work & Loss of energy & No measures \\
\hline & Low Power Factor & $\begin{array}{l}\text { Generator, } \\
\text { Compressor, } \\
\text { Dyeing, } \\
\text { Press M/c, } \\
\text { Compressor 2, } \\
\text { Boiler FD Fan, } \\
\text { Tumble dryer, } \\
\text { HT, }\end{array}$ & $\begin{array}{l}\text { Decreased load handling } \\
\text { capabilities of generators, } \\
\text { transformers and distribution } \\
\text { system. } \\
\text { Increased voltage, } \\
\text { Reduced Equipment life } \\
\text { Reduced efficiency of } \\
\text { generator, line losses }\end{array}$ & No measures \\
\hline & $\begin{array}{l}\text { Absence of automatic } \\
\text { moisture drainage }\end{array}$ & Compressor & Loss of Compressed air & No measures \\
\hline & $\begin{array}{l}\text { Wastage of boiler stack } \\
\text { gasses }\end{array}$ & Boiler & Loss of energy & No measures \\
\hline & $\begin{array}{l}\text { Non insulation of pipes } \\
\text { and valves }\end{array}$ & $\begin{array}{l}\text { Steam and } \\
\text { condensate pipes, } \\
\text { valves and } \\
\text { condensate recovery } \\
\text { tank }\end{array}$ & Loss of steam resource & No measures \\
\hline
\end{tabular}


ANNEXURE-III

Significant Environmental Aspects

\begin{tabular}{|c|c|c|c|c|c|c|c|c|c|c|c|}
\hline \multirow[t]{2}{*}{ 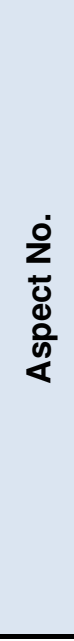 } & \multirow[t]{2}{*}{ 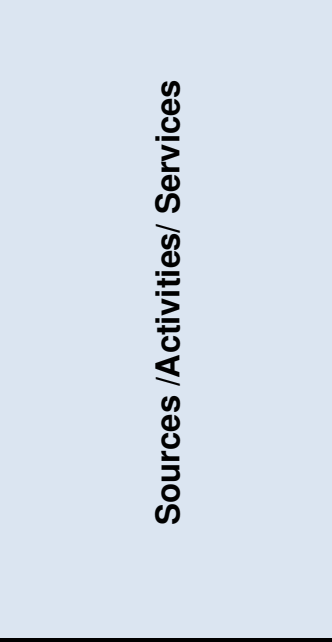 } & \multirow[t]{2}{*}{ 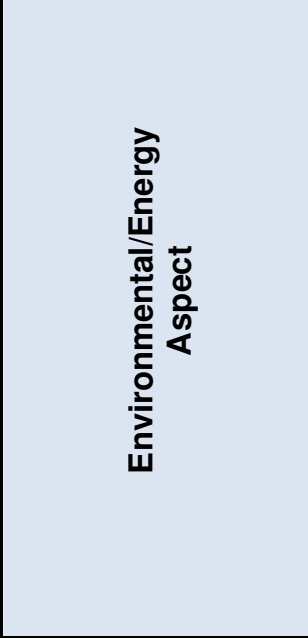 } & 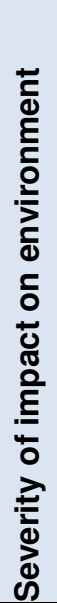 & 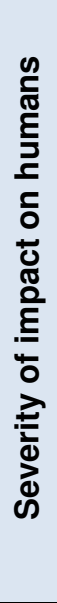 & 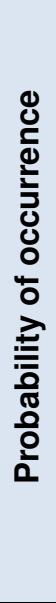 & 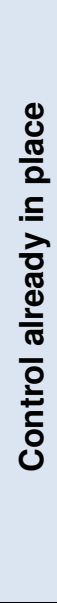 & 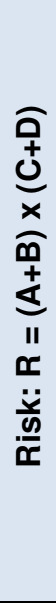 & 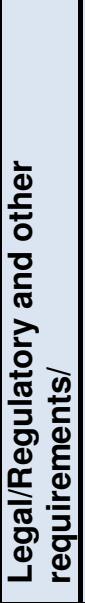 & $\begin{array}{l}\stackrel{0}{0} \\
\frac{\mathrm{J}}{5} \\
\frac{.0}{3} \\
\mathbf{z}\end{array}$ & 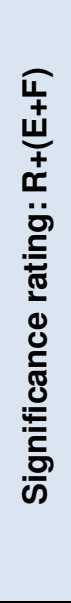 & 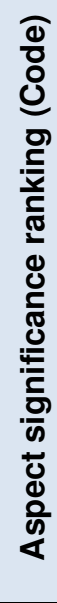 \\
\hline & & & $\mathrm{A}$ & $\mathrm{B}$ & $\mathbf{C}$ & D & $\mathbf{R}$ & $E$ & $\mathbf{F}$ & SR & $\mathrm{X}$ \\
\hline & $\begin{array}{l}\text { Bleaching, Dyeing, } \\
\text { Washing }\end{array}$ & Wastewater & 3 & 3 & 4 & 3 & 42 & 20 & 3 & 65 & 1 \\
\hline & Bleaching, Dyeing & Water wastages & 3 & 1 & 3 & 2 & 20 & 10 & 2 & 32 & 25 \\
\hline & $\begin{array}{l}\text { Oil heater, Stenter, } \\
\text { Compressor }\end{array}$ & $\begin{array}{l}\text { Wastages of } \\
\text { cooling water }\end{array}$ & 3 & 1 & 4 & 4 & 32 & 10 & 2 & 44 & 23 \\
\hline & Steam Boiler & Gaseous emissions & 4 & 1 & 5 & 2 & 35 & 20 & 4 & 59 & 4 \\
\hline & Generator (flue gas) & Gaseous emissions & 4 & 1 & 5 & 3 & 40 & 20 & 4 & 64 & 2 \\
\hline & $\begin{array}{l}\text { Therm oil heater (flue } \\
\text { gas) }\end{array}$ & Gaseous emissions & 4 & 0 & 4 & 2 & 24 & 20 & 4 & 48 & 17 \\
\hline & Stenter & VOCs & 3 & 2 & 4 & 3 & 35 & 20 & 4 & 59 & 5 \\
\hline & Tumble dryers & Noise & 3 & 3 & 3 & 2 & 30 & 20 & 3 & 53 & 12 \\
\hline & Finishing & Noise & 3 & 2 & 4 & 2 & 30 & 20 & 3 & 53 & 13 \\
\hline & Generator & Noise & 3 & 4 & 3 & 2 & 35 & 20 & 2 & 57 & 8 \\
\hline
\end{tabular}




\begin{tabular}{|c|c|c|c|c|c|c|c|c|c|c|c|}
\hline 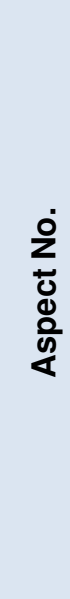 & 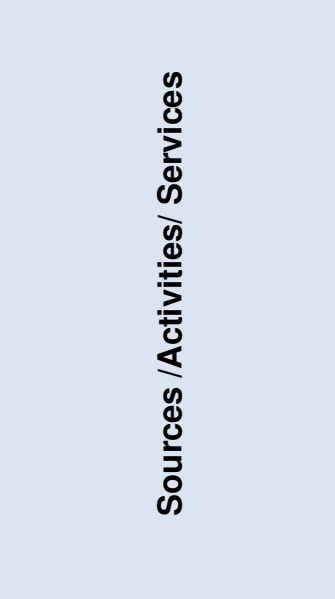 & 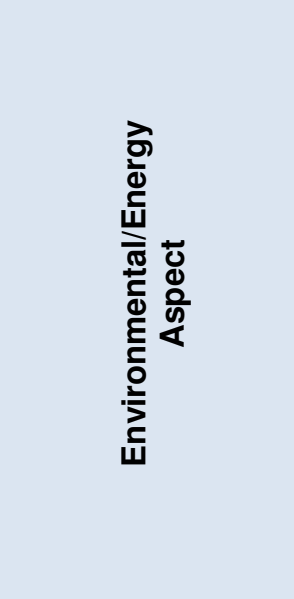 & 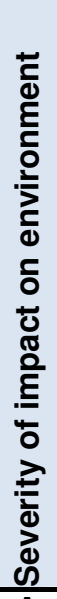 & 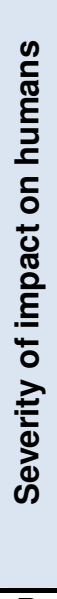 & 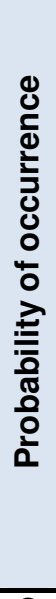 & 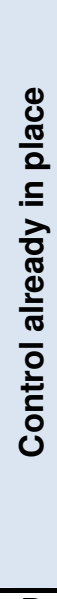 & 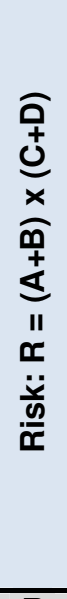 & 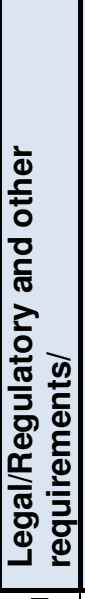 & $\begin{array}{l}\text { Ð } \\
\frac{C}{8} \\
\frac{.0}{5} \\
\mathbf{z}\end{array}$ & 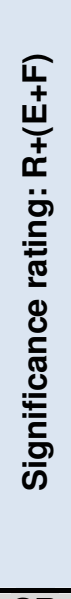 & 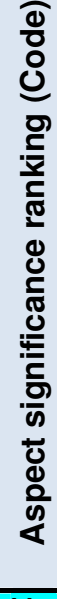 \\
\hline & & & A & $\mathrm{B}$ & $\mathbf{C}$ & $\mathbf{D}$ & $\mathbf{R}$ & $E$ & $\mathbf{F}$ & SR & $\bar{X}$ \\
\hline & Boiler & Noise & 3 & 4 & 3 & 2 & 35 & 20 & 2 & 57 & 9 \\
\hline & Processing & Solid waste & 1 & 1 & 5 & 2 & 14 & 10 & 0 & 24 & 27 \\
\hline & Packing & Solid waste & 3 & 3 & 3 & 3 & 36 & 10 & 3 & 49 & 16 \\
\hline & Chemical store & Solid waste & 4 & 1 & 5 & 4 & 45 & 10 & 4 & 59 & 7 \\
\hline & Office work & Solid waste & 1 & 1 & 2 & 2 & 8 & 10 & 0 & 18 & 28 \\
\hline & Maintenance & Solid waste & 3 & 2 & 5 & 2 & 35 & 10 & 2 & 47 & 20 \\
\hline & Hot processing & Poor ventilation & 1 & 3 & 5 & 5 & 40 & 10 & 2 & 52 & 14 \\
\hline & $\begin{array}{l}\text { Tumble dryers, oil } \\
\text { heater pumps, } \\
\text { broomwade } \\
\text { compressor }\end{array}$ & Open moving parts & 2 & 3 & 3 & 2 & 25 & 10 & 1 & 36 & 24 \\
\hline & $\begin{array}{l}\text { Processing hall and } \\
\text { Chemical store }\end{array}$ & Chemical handling & 4 & 3 & 4 & 3 & 49 & 10 & 2 & 61 & 3 \\
\hline & $\begin{array}{l}\text { Processing hall and } \\
\text { Chemical store }\end{array}$ & Chemical storage & 1 & 1 & 5 & 3 & 16 & 10 & 2 & 28 & 26 \\
\hline & Pipelines of steam & $\begin{array}{l}\text { wastage of steam } \\
\text { condensate }\end{array}$ & 3 & 2 & 5 & 2 & 35 & 10 & 2 & 47 & 21 \\
\hline & $\begin{array}{l}\text { Pipelines of steam } \\
\text { and steam } \\
\text { condensate }\end{array}$ & $\begin{array}{l}\text { Steam and } \\
\text { condensate } \\
\text { leakages }\end{array}$ & 3 & 2 & 5 & 2 & 35 & 10 & 3 & 48 & 19 \\
\hline & Processing & $\begin{array}{l}\text { Wastage of hot } \\
\text { water streams }\end{array}$ & 4 & 1 & 5 & 2 & 35 & 10 & 0 & 45 & 22 \\
\hline & $\begin{array}{l}\text { Stenter, Boiler, Therm } \\
\text { oil heater, Generator }\end{array}$ & $\begin{array}{l}\text { Discharge of hot } \\
\text { flue gases }\end{array}$ & 4 & 0 & 4 & 3 & 28 & 20 & 3 & 51 & 15 \\
\hline
\end{tabular}




\begin{tabular}{|c|c|c|c|c|c|c|c|c|c|c|c|}
\hline \multirow[t]{2}{*}{ 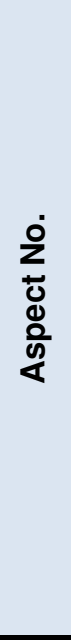 } & \multirow[t]{2}{*}{ 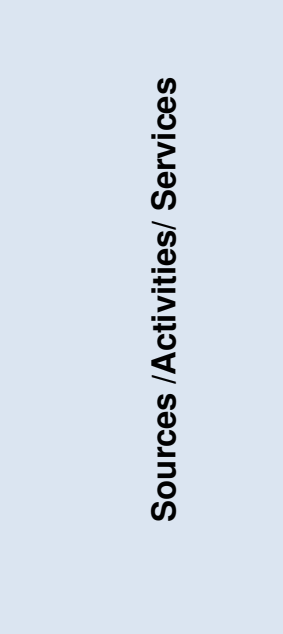 } & \multirow[t]{2}{*}{ 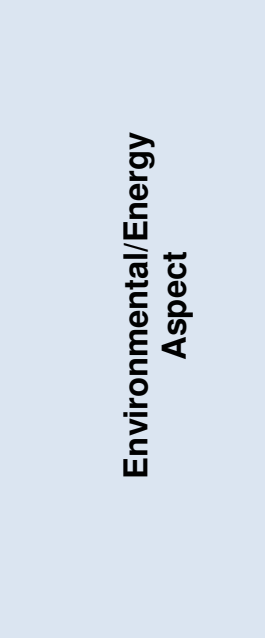 } & 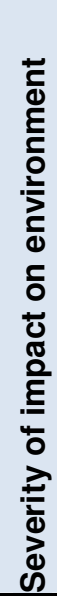 & 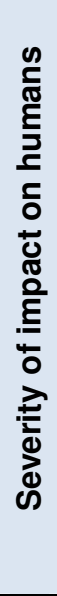 & 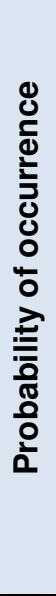 & 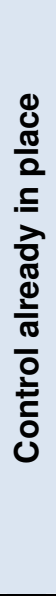 & 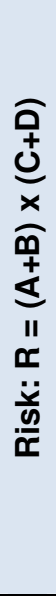 & 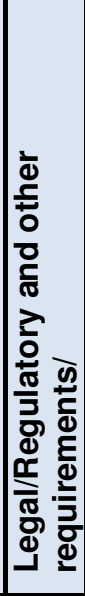 & $\begin{array}{l}\text { ญ } \\
\frac{0}{\mathbb{S}} \\
\frac{.0}{3} \\
\mathbf{Z}\end{array}$ & 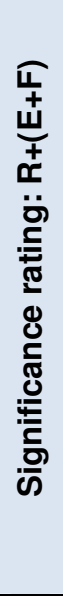 & 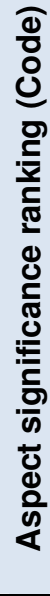 \\
\hline & & & A & $\bar{B}$ & $\bar{C}$ & $\bar{D}$ & $\mathbf{R}$ & $\bar{E}$ & $\mathbf{F}$ & $\overline{\text { SR }}$ & $\bar{X}$ \\
\hline & Process bath & $\begin{array}{l}\text { Uncontrolled } \\
\text { heating }\end{array}$ & 3 & 2 & 5 & 4 & 45 & 10 & 2 & 57 & 10 \\
\hline & $\begin{array}{l}\text { Steam condensate } \\
\text { storage tank }\end{array}$ & $\begin{array}{l}\text { Wastage of flash } \\
\text { steam }\end{array}$ & 3 & 2 & 5 & 4 & 45 & 10 & 2 & 57 & 11 \\
\hline
\end{tabular}

